\title{
Regulacje z zakresu międzynarodowego prawa podatkowego a wdrożenie działań BEPS
}

\begin{abstract}
International tax law in light of Base Erosion and Profit Shifting (BEPS): The article looks at the international regulations on income taxation and profit generated by entities conducting cross-border activity. Particular attention is given to current trends in international tax law and domestic legislation, which are related to BEPS schemes (Base Erosion and Profit Shifting). BEPS refers to corporate tax strategies used by transnational companies in order to shift profits from higher-tax locations to lower-tax ones. The author focuses on the Model Tax Convention on Income and on Capital, adopted by OECD in order to shape legal framework with a view to combat tax evasion. Proposals developed in this act are also discussed.
\end{abstract}

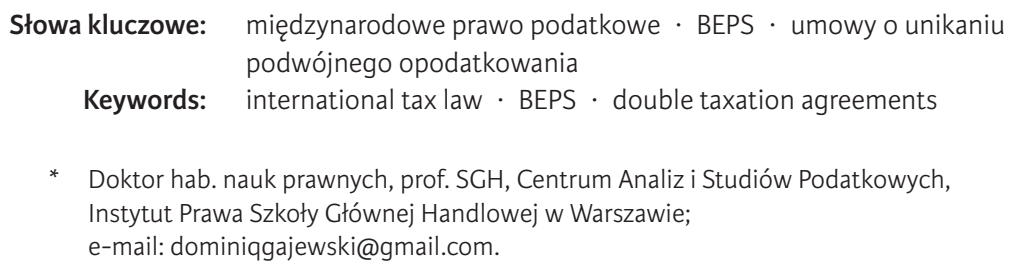

\section{Wstęp}

Opodatkowanie dochodów podmiotów gospodarczych działających transgranicznie jest uregulowane w krajowym prawie podatkowym, ale również w dużej mierze w unijnym i międzynarodowym prawie podatkowym. W dobie globalizacji rola regulacji międzynarodowych znacznie wzrosła, a wraz z tym nabrała znaczenia rola Modelowej konwencji OECD w sprawie podatku od dochodu i majątku (dalej: Modelowa konwencja OECD), która wyznacza kierunki zmian.

Wskazując wpływ międzynarodowego prawa podatkowego na proces opodatkowania dochodów podmiotów gospodarczych, należy zauważyć, że główną ideą przyświecającą tym regulacjom jest zamiar eliminowania negatywnych zjawisk ekonomicznych w postaci powstania podwójnego opodatkowania głównie 
w znaczeniu prawnym, ale równie często i ekonomicznym ${ }^{1}$. Ma to przyczynić się do zniesienia barier w międzynarodowym obrocie gospodarczym.

Inną istotną rolą międzynarodowego prawa podatkowego jest również zapewnienie efektywności krajowych systemów podatkowych, w szczególności przez współpracę administracji w sprawach podatkowych. Wynika to $\mathrm{z}$ faktu, że w dobie swobody w przepływie kapitału i majątku jurysdykcja podatkowa często nie jest w stanie efektywnie wymierzać należności podatkowych i je pobierać. A dodatkowo, już w fazie wymiaru zobowiązań podatkowych niezbędne okazuje się korzystanie z informacji znajdujących się w posiadaniu organów bądź podmiotów innych państw.

W epoce globalizacji ważną rolą międzynarodowego prawa podatkowego jest przeciwdziałanie międzynarodowemu unikaniu opodatkowania i uchylaniu się od niego. Skuteczne zapobieganie tym zjawiskom wiąże się ze skoordynowanym działaniem legislatorów i organów podatkowych wielu państw. Identyfikowanie konstrukcji i mechanizmów optymalizujących opodatkowanie, których wynikiem jest międzynarodowe unikanie opodatkowania, wymaga nie tylko przyjmowania spójnych instytucji prawnych, ale także współpracy między administracjami poszczególnych państw, zwłaszcza w przypadku holdingów prowadzących działalność na obszarze wielu różnych jurysdykcji podatkowych².

Międzynarodowe prawo podatkowe stanowi autonomiczny system prawny, którego źródłem zasadniczo są umowy międzynarodowe zawierające bezpośrednio efektywne normy prawne. Skutkuje to tym, że przepisy międzynarodowych umów podatkowych mogą być podstawą rozstrzygnięcia dokonanego przez organy administracji podatkowej. Normy te są również źródłem uprawnień, na które mogą powołać się podatnicy w sprawach podatkowych.

W państwach członkowskich Unii Europejskiej (w tym Polsce) normy prawne wynikające $z$ międzynarodowych umów podatkowych stanowią element wewnętrznego porządku prawnego. Pamiętać jednocześnie należy, że uregulowania z zakresu międzynarodowego prawa podatkowego odnoszą się do podatków dochodowych.

Tak więc istotną konstrukcją, która ma podstawowe znaczenie dla opodatkowania dochodów podmiotów gospodarczych działających transgranicznie, jest system umów przeciwdziałających podwójnemu opodatkowaniu. Filarem zdecydowanej większości bilateralnych umów w sprawie unikania podwójnego opodatkowania w zakresie podatków od dochodów i majątku jest Modelowa konwencja OECD³. Stanowi ona (jak również Komentarz do niej) niewiążą-

1 M. Uss, Cele umów o unikaniu podwójnego opodatkowania, „Kwartalnik Prawa Podatkowego" 2008, nr 3-4, s. 111.

2 D. Mączyński, Międzynarodowe prawo podatkowe, Warszawa 2015, s. 32-33.

3 Czasami taką rolę odgrywa również Modelowa konwencja ONZ. Szerzej zob. Z. Kukulski, Konwencja Modelowa OECD i Konwencja Modelowa ONZ w polskiej praktyce traktatowej, Warszawa 2015, s. 63-64. 
cy pisemny instrument prawa międzynarodowego (soft law) ${ }^{4}$. W praktyce istnienie "miękkiego zobowiązania” do respektowania jego treści przez strony umowy cechuje się tym, że państwo członkowskie powinno brać pod uwagę jego treść dopóty, dopóki państwo to nie wyrazi swoich zastrzeżeń w danym zakresie ${ }^{5}$. Mimo że Modelowa konwencja OECD nie zawiera wiążących norm prawnych dla państw członkowskich, nie sposób jednak nie dostrzec jej znaczenia i oddziaływania.

Istotnym instrumentem, który stanowi uzupełnienie Modelowej konwencji OECD, jest jej Komentarz. Choć nie ma on mocy wiążącej, odgrywa istotną rolę przy stosowaniu i interpretowaniu podatkowych umów międzynarodo$w$ ch $^{6}$. Często przypisuje się Komentarzowi rolę kreowania wielostronnych umów międzynarodowych. Wynika to z faktu, że zmiana treści Komentarza wywiera niezwykle istotny wpływ na sposób rozumienia i stosowania umów podatkowych. Na gruncie konkretnych umów może się bowiem okazać, że przy niezmienionej treści umowy międzynarodowej ulegnie zmianie sposób jej stosowania, i to wyłącznie na skutek zmiany Komentarza ${ }^{7}$. Nie ulega też wątpliwości, że rola Komentarza do Modelowej konwencji OECD rośnie w związku z wykorzystywaniem Komentarza przez sądy w procesie stosowania umów międzynarodowych.

Zmiany regulacji z zakresu prawa podatkowego międzynarodowego są obecnie sprofilowane na skuteczne przeciwdziałanie unikaniu opodatkowania na gruncie podatków dochodowych. Szczególnie odnosi się to do podmiotów, które działają transgranicznie (przedsiębiorstw wielonarodowych). Tendencja zmian w obszarze prawa podatkowego międzynarodowego i w konsekwencji przepisów wewnątrzkrajowych ma ścisły związek z projektem OECD Base Erosion and Profit Shifting (BEPS).

Projekt BEPS odnosi się do strategii planowania podatkowego wykorzystujących luki i rozbieżności w przepisach podatkowych dla ukrycia zysków lub ich transferowania do miejsc, w których podatnik wykazuje małą aktywność lub w ogóle jej brak, ale gdzie podatki są niskie, co skutkuje niewysokim opodatkowaniem lub brakiem opodatkowania podatkiem dochodowym ${ }^{8}$.

4 The Iterpretation of Income Tax Treaties with Particular Reference to teh Commentaries on the OECD Model, red. D.A. Ward, IBFD 2005, s. 38.

${ }_{5}$ M. Malicka, A. Zalasiński, Rola oficjalnego komentarza do Modelu Konwencji OECD w interpretacji umów dotyczących unikania podwójnego opodatkowania opartych na tym Modelu, „Kwartalnik Prawa Podatkowego” 2005, nr 1, s. 99.

${ }^{6}$ Szerzej zob. F. Engelem, Some Observations on the Legal Status of the Commentaries on the OECD Model, „Bulletin for International Taxation” 2006, No. 3, s. 106.

${ }^{7} \mathrm{~K}$. Vogel, The Influence of the OECD Commentaries on Treaty Intepretation, „Bulletin for International Taxation" 2000, No. 12, s. 613.

8 Zob. OECD, About Base Erosion and Profit Shifting (BEPS), http://www.oecd.org/ctp/ beps-about.htm. 
Projekt BEPS zawiera kompleksowy zestaw instrumentów (15 działań) mających przeciwdziałać zmniejszaniu podstawy opodatkowania i transferowi zysków, obejmuje pewne minimalne standardy, wspólne rozwiązania, wytyczne i najlepsze praktyki w dziedzinie opodatkowania, które państwa mogą wdrożyć do swoich porządków prawnych. Nie bez znaczenia jest fakt, że instrumenty te, w świetle prawa międzynarodowego publicznego, nie mają mocy wiążącej (soft law) ${ }^{9}$. Mimo to oczekuje się, że założenia wyrażone w pakiecie BEPS będą przyjmowane przez państwa uczestniczące $w$ wysiłkach nad jego opracowaniem ${ }^{10}$. Obecnie w wielu państwach (w tym Polsce) prace wdrożeniowe są $\mathrm{w}$ toku realizacji.

$\mathrm{W}$ poszczególnych działaniach zaproponowano środki mające na celu przeciwdziałanie unikaniu opodatkowania, które polegają głównie na zmianie przepisów krajowych lub międzynarodowych. Co do zasady, wprowadzenie tych zmian pozostawiono w gestii poszczególnych państw. W pewnych obszarach, w których brak jednolitego podejścia mógłby zaważyć na skuteczności zmian, ustalono minimalny standard, który państwa - uczestnicy prac w ramach BEPS - zobowiązały się wprowadzić.

Środki przewidziane w BEPS mają różnorodny charakter, część $\mathrm{z}$ nich nie wymaga implementacji do lokalnego porządku prawnego (między innymi zmiana Wytycznych OECD w sprawie cen transferowych dla przedsiębiorstw wielonarodowych i administracji podatkowych), część, co do zasady, wymaga zmian w przepisach lokalnych, część zaś musi być wprowadzona przez zmiany postanowień umów o unikaniu podwójnego opodatkowania (UPO). W odniesieniu do tych ostatnich środków w BEPS (działanie nr 15) przyjęto, że instrument wielostronny (wielostronna umowa międzynarodowa) będzie rozwiązaniem najbardziej efektywnym. Pozwala ona bowiem na dokonanie zmian w wielu umowach o UPO bez konieczności odrębnego negocjowania każdej z nich.

\section{Konwencja wielostronna}

W listopadzie 2016 r. opublikowany został tekst Konwencji wielostronnej mającej na celu wdrożenie środków przewidzianych w działaniach BEPS związanych $\mathrm{z}$ umowami o UPO - (Multilateral Convention to Implement Tax Treaty Related Measures to Prevent Base Erosion and Profit Shifting $)^{11}$. Celem Konwencji wielostronnej (dalej: Konwencja) jest odpowiednie zmodyfikowanie regulacji wyni-

9 Konwencja OECD pozwala w art. 5 lit. b wydać „zalecenia” członkom, przy czym nie reguluje bliżej ich charakteru prawnego. Szerzej zob. M. Dudzic, Przeglad prac OECD związanych z BEPS w kontekście suwerenności państwa, „Kwartalnik Prawa Podatkowego” 2014, nr 3, s. 88-89.

${ }^{10}$ E. Eberhartinger, M. Petutschnig, Practicing Experts' Views on BEPS: A Critical Analysis, WU International Taxation Research Paper Series No. 27, 2015, s. 1-35.

${ }^{11} \mathrm{Http} / / /$ www.oecd.org/treaties/multilateral-convention-to-imlement-tax-treaty-related-measures-to-prevent-beps.htm. 
kających z umów o UPO obowiązujących między poszczególnymi państwami. Nie będzie się to jednak odbywało przez bezpośrednie wprowadzenie zmian do tekstów umów. Umowy mają być stosowane wraz z przepisami Konwencji wielostronnej, która będzie odpowiednio modyfikowała ich postanowienia. Ze względu na wskazany cel Konwencji wielostronnej i fakt, że może ona potencjalnie objąć nawet 3000 umów o UPO, za kluczowe przyjęto takie skonstruowanie jej postanowień, aby umożliwić państwom stronom odpowiednie dopasowanie poszczególnych rozwiązań do własnych celów dotyczących polityki podatkowej. Konwencja w zamierzeniu ma pogodzić różne oczekiwania poszczególnych jurysdykcji stron Konwencji przy jednoczesnym zapewnieniu realizacji celów BEPS. Ma to być możliwe ze względu na przyjęte założenia Konwencji:

- Konwencja ma modyfikować jedynie umowy o UPO wskazane przez strony Konwencji (w tym zakresie wymagana jest notyfikacja depozytariuszowi Konwencji) - możliwe jest więc wyłączenie przez stronę Konwencji jej zastosowania wobec niektórych zawartych przez nią umów o UPO,

- jeśli osiągnięcie tzw. minimalnego standardu określonego w ramach BEPS możliwe jest w różny sposób, Konwencja pozostawia wybór tego sposobu państwu stronie,

- wobec postanowień Konwencji, które nie mają na celu osiągnięcia minimalnego standardu, możliwość rezygnacji przez stronę Konwencji z ich stosowania jest zasadniczo możliwa i może przybrać postać:

a) niestosowania danego postanowienia w odniesieniu do wszystkich umów o UPO zawartych przez jurysdykcję strony Konwencji lub

b) niestosowania danego postanowienia $\mathrm{w}$ odniesieniu do umów, w których poszczególne postanowienia obowiązujących umów mają określoną treść ${ }^{12}$.

Rozwiązania alternatywne lub opcjonalne znajdą zastosowanie $w$ relacji między danymi dwoma państwami (a zatem $\mathrm{w}$ ramach stosowania wybranej umowy o UPO) jedynie $\mathrm{w}$ razie wyboru ich przez obie strony umowy o UPO. Mając na uwadze istotę i wpływ wszystkich działań BEPS na wewnątrzkrajowe prawo podatkowe, należy przeanalizować nie tylko ich założenia, ale i konsekwencje.

\section{Działanie $\mathrm{nr} 1$}

Pierwszym z działań są wyzwania podatkowe elektronicznego rynku ${ }^{13}$. Są one wyzwaniem dla unikania opodatkowania, które przejawia się między innymi

12 M. Leconte, M. Raińczuk, Konwencja Wielostronna (BEPS działanie nr 15) - omówienie najistotniejszych zagadnień, „Monitor Podatkowy” 2017, nr 5, s. 19-20.

13 OECD, Addessing the Tax Challenges of the Digital Economy. Action 1: 2015 Final Report, Paryż 2015, https://doi.org/10.1787/9789264241046-en. 
w mobilności dóbr materialnych, użytkowników czy funkcji biznesowych, tendencji do monopolizacji lub oligopolizacji.

Niewątpliwie w obszarze gospodarki cyfrowej istnieją istotne trudności w implementacji zasad podatkowych. Ponadto zaprezentowanie rozwiązań w sposób kompleksowy, uwzględniający zarówno podatki bezpośrednie, jak i pośrednie (VAT), jest niezwykle trudne. Należy mieć również na uwadze fakt, że gospodarki cyfrowej nie można traktować jako odrębnej części gospodarki wymagającej niezależnych od obecnie obowiązujących (wdrażanych) regulacji podatkowych ${ }^{14}$.

W polskim ustawodawstwie podatkowym nastąpiły zmiany ${ }^{15}$ między innymi w określaniu miejsca świadczenia dla potrzeb ustawy z 11 marca $2004 \mathrm{r}$. o podatku od towarów i usług, t.j. Dz.U. 2011, nr 177, poz. 1054, ze zm., dla usług telekomunikacyjnych, nadawczych i elektronicznych świadczonych na rzecz ostatecznych konsumentów (nie podatników), zlokalizowanych w Unii Europejskiej. Wprowadzono również fakultatywne rozwiązanie upraszczające tzw. mały punkt kompleksowej obsługi (MOSS), z którego krajowa administracja podatkowa przekazuje podatek do państwa członkowskiego konsumpcji ${ }^{16}$.

\section{Działanie nr 2}

Kolejnym działaniem jest neutralizacja efektów hybrydowych struktur wykorzystujących niespójność systemów podatkowych ${ }^{17}$. Ma ono przeciwdziałać wykorzystywaniu luk na styku różnych systemów podatkowych do sztucznego obniżania dochodów lub przesunięcia zysków do jurysdykcji z niskim opodatkowaniem przy niewielkim lub zerowym zaangażowaniu w działalność gospodarczą w tych państwach.

Rozwiązanie tego problemu powinno skupiać się na stworzeniu krajowych przepisów neutralizujących efekty porozumień hybrydowych (np. podwójnego nieopodatkowania, podwójnego odliczenia tego samego kosztu, długoterminowego odroczenia płatności podatku) oraz zmian w Modelowej konwencji OECD. Proponowane jest rozwiązanie zakładające stworzenie zasad powiązania rozliczenia podatkowego płatności dotyczącej podmiotu hybrydowego (umowy hybrydowej) w jednym państwie z rozliczeniem tej płatności w drugim państwie ${ }^{18}$.

14 A. Wieśniak-Wiśniewska, M. Czerwiński, Świat podatków po projekcie BEPS i jego wpływ na polskich podatników, „Przegląd Podatkowy” 2016, nr 6, s. 22-31.

15 Ustawa z 25 lipca 2014 r. o zmianie ustawy o podatku od towarów i usług oraz ustawy - Ordynacja podatkowa, Dz.U. poz. 1171.

${ }^{16}$ Ustawa z 29 sierpnia 2014 r. o zmianie ustawy o podatku dochodowym od osób prawnych, ustawy o podatku dochodowym od osób fizycznych oraz niektórych innych ustaw, Dz.U. poz. 1328, ze zm.

17 OECD, Neutralising the Effects of Hybrid Mismatch Arrangements. Action 2: 2015 Final Report, Paryż 2015, https://doi.org/10.1787/9789264241138-en.

18 A. Wieśniak-Wiśniewska, M. Czerwiński, Świat podatków po projekcie BEPS, op. cit., s. $22-31$. 
W polskim ustawodawstwie podatkowym konieczne jest ustanowienie przepisów tworzących powiązanie między opodatkowaniem jednej ze stron transakcji w danym państwie a opodatkowaniem drugiej strony w innym państwie i pozwalające odmówić zwolnienia dywidend dla płatności odliczonych od podatku. Potrzebne są także przepisy poprawiające zasady funkcjonowania inwestycji zagranicznych typu offshore i zwiększające przejrzystość podatkową podmiotów pośredniczących.

Postulowane zmiany zostały już rozpoczęte $\mathrm{w}$ ustawie o podatku dochodowym od osób prawnych na mocy dodanego art. 20 ust. 16 ${ }^{19}$, zgodnie z którym wyłączone zostało prawo do korzystania ze zwolnienia od podatku w przypadku otrzymania dywidend i innych dochodów (przychodów) z tytułu udziału w zyskach osób prawnych, podlegającego zaliczeniu do kosztów uzyskania przychodów lub odliczeniu w spółce wypłacającej (tzw. pożyczka partycypacyjna ${ }^{20}$.

Rekomendacje zawarte w tych działaniach koncentrują się wokół przeciwdziałania wykorzystywaniu różnic w traktowaniu do celów podatkowych pewnych podmiotów przez różne jurysdykcje. Te rozbieżności są często wykorzystywane do osiągnięcia korzyści podatkowych, w szczególności podwójnego nieopodatkowania. Mając to na uwadze, działania nr 2 przewidują nie tylko rekomendacje odnoszące się do zmian, które powinny zostać wprowadzone w prawie wewnątrzkrajowym, ale i rekomendacje zmian w Modelowej konwencji OECD. Te rekomendacje powinny być wprowadzone do obowiązujących umów o UPO za pomocą Konwencji wielostronnej.

Na szczególną uwagę zasługuje problematyka z zakresu ograniczenia korzyści wynikających z zastosowania metody wyłączenia (zwolnienia) - art. 5 Konwencji wielostronnej. Przewiduje ona trzy różne sposoby ograniczania korzyści wynikających z zastosowania metody wyłączenia (zwolnienia). Polegają one na zastąpieniu metody wyłączenia (zwolnienia) metodą zaliczenia zwykłe$\mathrm{go}^{21} \mathrm{w}$ państwie rezydencji podatnika:

- gdy na mocy umowy dochód lub majątek korzysta ze zwolnienia lub opodatkowania obniżoną stawką w państwie źródła,

- w stosunku do dywidend, gdy zgodnie z lokalnymi regulacjami w państwie źródła wypłata dywidendy obniża podstawę opodatkowania podmiotu wypłacającego,

19 Ustawa z 29 sierpnia 2014 r. o zmianie ustawy o podatku dochodowym od osób prawnych, ustawy o podatku dochodowym od osób fizycznych oraz niektórych innych ustaw, Dz.U. poz. 1328, ze zm.

${ }^{20}$ A. Wieśniak-Wiśniewska, M. Czerwiński, Świat podatków po projekcie BEPS, op. cit., s. 22-31.

${ }^{21}$ Możliwość odliczenia od podatku w państwie rezydencji podatku zapłaconego w państwie źródła jest ograniczona do wysokości podatku należnego od danego dochodu/ majątku w państwie rezydencji. 
- w każdym przypadku, gdy zastosowanie miałaby znaleźć metoda wyłączenia; $w$ tej sytuacji dodatkowo wprowadzona zostaje zasada, zgodnie z którą w sytuacji, gdy dochód lub majątek może być opodatkowany wyłącznie w państwie źródła, państwo rezydencji ma prawo do zastosowania do opodatkowania pozostałego dochodu lub majątku stawki uwzględniającej ten wyłączony $\mathrm{z}$ opodatkowania dochód lub majątek (zmiana ta polegałaby na całkowitym zastąpieniu metody wyłączenia metodą zaliczenia zwykłego - analogiczną jak uregulowana w art. 23b Modelowej konwencji OECD) $)^{22}$.

Każda ze stron Konwencji ma możliwość wyboru jednego z powyższych sposobów ograniczenia korzyści lub niezastosowania żadnego z nich. Co do zasady, wybrany przez stronę sposób będzie miał zastosowanie wobec jej rezydentów podatkowych, przy czym postanowienia Konwencji wielostronnej pozwalają również na uniknięcie negatywnych konsekwencji asymetrycznego wyboru sposobu - w szczególności państwo, które nie wybrało żadnego sposobu przewidzianego w art. 5 Konwencji, może zastrzec, że nie będzie ona miała w ogóle zastosowania do jednej lub wielu (wszystkich) umów, których jest stroną. Strona, która nie wybrała ostatniego sposobu (zastąpienie metody wyłączenia metodą zaliczenia), może zabronić w odniesieniu do jednej lub wielu (wszystkich) umów, których jest stroną, drugiej stronie wyboru tego sposobu. Wprowadzenie powyższej regulacji może znacznie ograniczyć zastosowanie metody wyłączenia jako metody unikania podwójnego opodatkowania, w szczególności w sytuacjach, w których mogłoby ono prowadzić do podwójnego nieopodatkowania ${ }^{23}$.

Istotna problematyka z zakresu działań (nr 2) dotyczy również podmiotów o podwójnej rezydencji podatkowej, co wynika wprost $\mathrm{z}$ art. 4 Konwencji wielostronnej. Postanowienie, zgodnie z którym, gdy osoba niebędąca osobą fizyczną jest rezydentem obu państw stron umowy, odpowiednie organy państwa (organy podatkowe) podejmą starania ( $w$ drodze procedury wzajemnego porozumienia), aby ustalić właściwą rezydencję podmiotu. Ustalenie to będzie dokonywane $\mathrm{z}$ uwzględnieniem miejsca faktycznego zarządu (place of effective management), siedziby (place where it is incorporated) oraz innych czynników. Jeżeli porozumienie nie zostanie osiągnięte, osoba ta nie będzie uprawniona do korzystania z ulg i zwolnień przewidzianych $\mathrm{w}$ umowie (chyba że odpowiednie organy postanowią inaczej). Jest to równoznaczne z tym, że od momentu wejścia w życie omawianego rozwiązania konflikty rezydencji (dotyczące podmiotów innych niż osoby fizyczne) będą rozstrzygane indywidualnie w odniesieniu do poszczególnych przypadków, w przeciwieństwie do automatycznego

${ }^{22}$ M. Leconte, M. Raińczuk, Konwencja Wielostronna (BEPS działanie nr 15), op. cit., s. $19-20$.

${ }^{23}$ Ibidem. 
rozstrzygania tej sytuacji, jak to jest obecnie. Zastosowanie tego artykułu do umów, do których ma zastosowanie Konwencja, nie jest obligatoryjne ${ }^{24}$.

Kolejna ważna problematyka z zakresu działań (nr 2) odnosi się do podmiotów transparentnych podatkowo, co wynika wprost $z$ art. 3 Konwencji wielostronnej. Postanowienie, zgodnie z którym dochód osiągany przez podmiot lub w ramach porozumienia traktowane jako transparentne bądź częściowo transparentne zgodnie z prawem podatkowym którejś ze stron umowy powinien być uznany za dochód rezydenta strony umowy tylko w takim zakresie, w jakim ten dochód jest traktowany do celów opodatkowania przez tę stronę jako dochód jej rezydenta. Postanowienie to zmierza do doprecyzowania możliwości korzystania z umowy o UPO w razie osiągania dochodów z wykorzystaniem podmiotów transparentnych. Zastosowanie art. 3 Konwencji wielostronnej do umów, do których ma zastosowanie Modelowa konwencja OECD, nie jest obligatoryjne. Konwencja wielostronna przewiduje w tym zakresie możliwość zgłoszenia zastrzeżeń, włącznie z niestosowaniem tego artykułu do wszystkich umów, do których zastosowanie ma Modelowa konwencja OECD ${ }^{25}$.

\section{Działanie nr 3}

Trzecim działaniem jest wzmocnienie zasad opodatkowania kontrolowanych podmiotów zagranicznych (CFC $)^{26}$. Ma to przeciwdziałać lokalizacji spółek $\mathrm{z}$ grupy podmiotów powiązanych $\mathrm{w}$ jurysdykcjach $\mathrm{z}$ niskim opodatkowaniem w celu przesuwania zysków lub odroczenia opodatkowania.

W zakresie zagranicznych spółek kontrolowanych (CFC) rekomendowane jest poddanie opodatkowaniu w danym państwie - jako dochodu przypisanego do podmiotu krajowego - dochodu z zysków, jakie osiągnął podmiot zależny, spełniający kryteria CFC, będący rezydentem podatkowym państwa stosującego preferencyjne zasady opodatkowania.

Istotną regulacją $\mathrm{w}$ tym zakresie jest wprowadzenie do ustawy o podatku od towarów i usług ${ }^{27}$ opodatkowania w Polsce dochodów osiąganych przez zagraniczne spółki kontrolowane (tzw. regulacje CFC), co oznacza objęcie opodatkowaniem dochodów pasywnych, przesuwanych do państw o preferencyjnych systemach podatkowych, jednolitą stawką 19\% z uwzględnieniem kilku wyłączeń, w tym wyłączenia dla podmiotów z UE - pod warunkiem prowadzenia rzeczywistej działalności gospodarczej ${ }^{28}$.

${ }^{24}$ Ibidem.

${ }^{25}$ Ibidem.

26 OECD, Designing Effective Controlled Foreign Company Rules. Action 3: 2015 Final Report, Paryż 2015, https://doi.org/10.1787/9789264241152-en.

27 Ustawa z 25 lipca 2014 r. o zmianie ustawy o podatku od towarów i usług oraz ustawy - Ordynacja podatkowa, Dz.U. poz. 1171.

28 Art. 24a ustawy z 15 lutego 1992 r. o podatku dochodowym od osób prawnych, Dz.U. nr 21, poz. 86, ze zm.; dalej: u.p.d.p. Zob. W. Missala, Opodatkowanie zagranicznych spółek 


\section{Działanie nr 4}

Ważnym działaniem jest ograniczenie erozji podstawy opodatkowania przez odliczanie odsetek i innych opłat za usługi finansowe ${ }^{29}$. Ma ono przeciwdziałać wykorzystaniu mobilności pieniądza do unikania opodatkowania przez odliczanie odsetek i innych opłat za usługi finansowe dokonywane na rzecz osób trzecich i podmiotów powiązanych. Rozwiązaniem tego problemu są zmiany w zakresie krajowych przepisów podatkowych w obszarze tzw. niedostatecznej kapitalizacji.

$\mathrm{W}$ polskich regulacjach podatkowych ${ }^{30}$ istotnym zmianom uległy przepisy o niedostatecznej kapitalizacji realizujące postulat przeciwdziałania erozji podstawy opodatkowania przez wydatki odsetkowe. Związane to jest między innymi z zastąpieniem wartości trzykrotności kapitału zakładowego „kapitałem własnym” (współczynnik zadłużenia 1:1), wprowadzeniem konieczności uwzględnienia również pożyczek od udziałowców pośrednich i podmiotów powiązanych pośrednio przez tego samego udziałowca i wskazaniem nowego momentu, na który należy liczyć wskaźnik zadłużenia, tj. ostatniego dnia miesiąca poprzedzającego dzień zapłaty odsetek ${ }^{31}$.

\section{Działanie nr 5}

Celem działania nr 5 jest efektywne zwalczanie szkodliwych praktyk podatkowych przy uwzględnieniu transparentności i treści ekonomicznej (substance) transakcji ${ }^{32}$. Głównymi problemami, które się z tym wiążą, są: brak

kontrolowanych (CFC) - co czeka polskich przedsiębiorców?, „Przegląd Podatkowy” 2014, nr 11, s. 15-20; B. Kuźniacki, Polskie CFC rules w świetle międzynarodowego prawa podatkowego. Wybrane aspekty wystąienia ryzyka niezgodności CFC rules $z$ umowami o unikaniu podwójnego opodatkowania (1), „Przegląd Podatkowy” 2015, nr 1, s. 37-48; B. Kuźniacki, Polskie CFC rules w świetle międzynarodowego prawa podatkowego. Zagraniczna i polska praktyka legislacyjna wzakresie relacji pomiędzy CFC rules a umowami UPO, „Przegląd Podatkowy” 2015, nr 3, s. 44-55; A. Wieśniak-Wiśniewska, M. Czerwiński, Świat podatków po projekcie BEPS, op. cit., s. 22-31.

${ }^{29}$ OECD, Limiting Base Erosion Involving Interest Deductions and Other Financial Payments. Action 4: 2015 Final Report, Paryż 2015, https://doi.org/10.1787/9789264241176-en.

${ }^{30}$ Między innymi ustawa z 29 sierpnia 2014 r. o zmianie ustawy o podatku dochodowym od osób prawnych, ustawy o podatku dochodowym od osób fizycznych oraz niektórych innych ustaw, Dz.U. poz. 1328, ze zm.

31 Art. 16 ust. 1 pkt. 60 i 61 u.p.d.p. Zob. S. Krempa, P. Woźniakiewicz, Niedostateczna kapitalizacja - zasady odliczania odsetek do kosztów uzyskania przychodów od 2015 r. Metoda podstawowa (1), „Przegląd Podatkowy” 2014, nr 12, s. 18-24; S. Krempa, P. Woźniakiewicz, Niedostateczna kapitalizacja - zasady odliczania odsetek do kosztów uzyskania przychodów od 2015 r. Metoda alternatywna oraz przepisy międzyczasowe (2), „Przegląd Podatkowy" 2015, nr 1, s. 21-27; A. Wieśniak-Wiśniewska, M. Czerwiński, Świat podatków po projekcie BEPS, op. cit., s. 22-31.

32 OECD, Countering Harmful Tax Practices More Effectively, Taking into Account Transparency and Substance. Action 5: 2015 Final Report, Paryż 2015, https://doi.org/10.1787/ 9789264241190-en. 
odpowiedniej metodologii w definiowaniu wymogu istotnej aktywności dla oceny systemów preferencyjnych w kontekście reżimów z liberalnymi przepisami w sferze własności intelektualnej, niska transparentność w zakresie korzystania z preferencji i brak wymiany informacji o interpretacjach podatkowych czy porozumieniach mogących skutkować unikaniem opodatkowania.

Zaproponowanymi rozwiązaniami są wytyczne w zakresie kryteriów oceny treści ekonomicznej transakcji (substance). Ponadto przygotowanie ram współpracy w zakresie obowiązkowej wymiany informacji między administracjami podatkowymi bez wezwania na temat wydawanych interpretacji podatkowych (tzw. tax rulings) w zakresie preferencyjnych zasad opodatkowania. Wytyczne zawierają sformułowanie nowego/zmodyfikowanego wymogu działalności o istotnym zakresie w odniesieniu do preferencyjnych zasad stosowanych do wartości niematerialnych i prawnych (patent box regimes) ${ }^{33}$.

Polski ustawodawca podjął już liczne działania, które ukierunkowane są na usprawnienie wymiany informacji z innymi państwami, co wpisuje się w obszar poprawy transparentności. Mając to na uwadze, podpisano 14 umów o wymianie informacji w sprawach podatkowych, $w$ tym $z$ tzw. rajami podatkowymi: Wyspą Man, Jersey, Guernsey, San Marino, Andorą, Gibraltarem, Belize, Wspólnotą Dominiki, Grenadą, Wspólnotą Bahamów, Liberią, Bermudami, Brytyjskimi Wyspami Dziewiczymi i Kajmanami ${ }^{34}$. Jeżeli chodzi o przegląd preferencyjnych reżimów podatkowych, to Minister Finansów wydał rozporządzenie ${ }^{35}$ aktualizujące listę tzw. rajów podatkowych, zmniejszając ich liczbę, co wiązało się z wytycznymi OECD w tym zakresie i zawieraniem ww. umów o wymianie informacji ${ }^{36}$.

Obowiązek uwzględniania treści ekonomicznej (substance over form), choć pojawia się już od pewnego czasu w przepisach podatkowych ${ }^{37}$, obecnie staje się kluczowym elementem nowo wprowadzanych rozwiązań uszczelniających system podatkowy, czego przykładem jest regulacja CFC (art. 24 u.p.d.p.),

33 A. Wieśniak-Wiśniewska, M. Czerwiński, Świat podatków po projekcie BEPS, op. cit., s. $22-31$.

${ }^{34}$ Ministerstwo Finansów, Wykaz umów o wymianie informacji $w$ sprawach podatkowych, http://www.finanse.mf.gov.pl/.

35 Rozporządzenie Ministra Finansów z 23 kwietnia 2015 r. w sprawie określenia krajów i terytoriów stosujących szkodliwą konkurencję podatkową w zakresie podatku dochodowego od osób prawnych, Dz.U. poz. 600.

${ }_{36}$ A. Wieśniak-Wiśniewska, M. Czerwiński, Świat podatków po projekcie BEPS, op. cit., s. $22-31$.

${ }^{37} \mathrm{Na}$ przykład w tzw. klauzuli beneficial owner w art. 21 u.p.d.p. i zawartych przez Polskę umów UPO. Zob. M. Wilk, Klauzula rzeczywistego beneficjenta (beneficial ownership) po zmianach w Komentarzu do Konwencji Modelowej OECD w sprawie podatku od dochodu i majątku z 2014 r., „Przegląd Podatkowy” 2015, nr 9, s. 49-54. 
klauzula antyabuzywna implementowana w art. 22c u.p.d.p. oraz klauzula przeciwko unikaniu opodatkowania (art. 119a Ordynacji podatkowej ${ }^{38}$ ).

\section{Działanie nr 6}

Kolejnym działaniem jest zapobieganie nadużyciom w wykorzystaniu udogodnień traktatowych ${ }^{39}$. Głównym problemem z tym związanym jest pozbawianie państw wpływów podatkowych przez podatników zaangażowanych $\mathrm{w}$ tzw. treaty shopping $\mathrm{i}$ inne strategie unikania opodatkowania $\mathrm{z}$ wykorzystaniem umów o UPO czerpiących korzyści traktatowe w sytuacjach, gdy korzyści te nie powinny być przyznane.

Najważniejszymi działaniami w tym zakresie są zmiany w Modelowej konwencji OECD oraz stworzenie krajowych zasad polityki podatkowej mających zastosowanie przy zawieraniu umów o UPO. W konsekwencji mają one ograniczyć wykorzystanie preferencji traktatowych (w ramach umów o UPO) w nieuprawnionych okolicznościach przez wprowadzenie klauzuli ogólnej (tzw. general anti-avoidance rules, GAAR) do Modelowej konwencji OECD, wprowadzenia klauzuli ograniczenia korzyści (Limitation of Benefits clause, LOB) do umów $\mathrm{UPO}^{40}$.

Poza działaniami polegającymi na modyfikowaniu umów o UPO przez włączenie do nich reguł antyabuzywnych (Principle Purpose Test - PPT, LOP) konieczne jest również wsparcie odpowiednimi regułami na poziomie krajowym. Od 1 stycznia $2016 \mathrm{r}$. wprowadzono do ustawy o zmianie ustawy o podatku dochodowym od osób fizycznych ${ }^{41}$ szczególną klauzulę zapobiegającą unikaniu opodatkowania (tzw. specific anti-avoidance rules, SAAR). Klauzula wyłącza prawo do zwolnienia $\mathrm{z}$ opodatkowania dywidend $\mathrm{w}$ sytuacji, gdy ich wypłata wynika z zawarcia umowy lub dokonania innej czynności prawnej, lub wielu powiązanych czynności prawnych, których głównym lub jedynym z głównych celów było uzyskanie zwolnienia od podatku dochodowego, a czynności te nie mają rzeczywistego charakteru, tzn. nie są dokonywane z uzasadnionych przyczyn ekonomicznych ${ }^{42}$. Wprowadzenie klauzuli SAAR - będącej imple-

${ }^{38}$ Ustawa z 29 sierpnia 1997 r. ustawa - Ordynacja podatkowa, t.j. Dz.U. 2015, poz. 613, ze zm.

39 OECD, Preventing the Granting of Treaty Benefits in Inappropriate Circumstances. Action 6: 2015 Final Report, Paryż 2015, https://doi.org/10.1787/9789264241695-en.

40 A. Wieśniak-Wiśniewska, M. Czerwiński, Świat podatków po projekcie BEPS, op. cit., s. 2231; A. Olesińska, Klauzula ogólna zapobiegająca unikaniu opodatkowania, Toruń 2016, s. 67-78.

${ }^{41}$ Ustawa z 9 października 2015 r. o zmianie ustawy o podatku dochodowym od osób fizycznych, ustawy o podatku dochodowym od osób prawnych oraz niektórych innych ustaw, Dz.U. poz. 1932.

${ }^{42}$ Art. 22c u.p.d.p. Sposób implementacji klauzuli spotkał się jednak z krytyką w doktrynie. Zob. F. Majdowski, Implementacja klauzuli antyhybrydowej oraz tzw. małej klauzuli antyabuzywnej do ustawy o podatku dochodowym od osób prawnych na skutek „uszczelnie- 
mentacją do wewnątrzkrajowego porządku prawnego dyrektywy Rady (UE) 2015/121 z 27 stycznia 2015 r. zmieniającej dyrektywę 2011/96/UE w sprawie wspólnego systemu opodatkowania mającego zastosowanie w przypadku spółek dominujących i spółek zależnych różnych państw członkowskich ${ }^{43}$ (tzw. dyrektywy Parent-Subsidiary) - służy zarówno przeciwdziałaniu nadużyciom swobód unijnych, jak i uprawnień traktatowych ${ }^{44}$.

Istotną regulacją wprowadzoną przez polskiego ustawodawcę jest klauzula przeciwko unikaniu opodatkowania (art. 119a Ordynacji podatkowej). W dniu 15 lipca 2016 r. do ustawy - Ordynacja podatkowa ${ }^{45}$ wprowadzony został dział IIIA, inkorporujący w polskim systemie prawa podatkowego konstrukcję klauzuli o przeciwdziałaniu unikaniu opodatkowania. Istotą konstrukcji klauzuli o przeciwdziałaniu unikaniu opodatkowania stał się art. 119a, zgodnie z którym czynność dokonana przede wszystkim w celu osiągnięcia korzyści podatkowej, sprzecznej w danych okolicznościach z przedmiotem i celem przepisu ustawy podatkowej, nie skutkuje osiągnięciem korzyści podatkowej, jeżeli sposób działania podatnika był sztuczny. Oznacza to, że zakwestionowane na gruncie prawa podatkowego czynności pozostają ważne i skuteczne w sferze prawa cywilnego, lecz ich skutki podatkowe zostają określone inaczej niż wynikałoby to z treści stosunku prawnego, który został oceniony przez organy podatkowe jako sztuczny ${ }^{46}$.

Charakter takiej klauzuli wpisuje się w całość działań podejmowanych $\mathrm{w}$ toku prac $\mathrm{w}$ obrębie BEPS i może wspierać podobną klauzulę w umowach o UPO proponowaną w działaniu 6 (zwłaszcza w razie obchodzenia prawa krajowego z wykorzystaniem uprawnień traktatowych).

Abstrahując od powyższych konstrukcji w zakresie przepisów krajowych zmienianych przez ustawodawcę w ostatnich latach, Polska jest zaangażowana w liczne działania na arenie międzynarodowej. Przejawia się to w aktywnym dążeniu do zawierania protokołów zmieniających umowy o UPO lub nowych umów, w szczególności z następującymi modyfikacjami:

- usunięcie klauzul tax sparing umożliwiających fikcyjne zaliczenie podatku ${ }^{47}$,

nia” dyrektywy o spółkach matkach i spółkach córkach, „Przegląd Podatkowy” 2016, nr 2, s. 35-42; K. Gil, Komentarz do art. 22c [w:] Podatek dochodowy od osób prawnych. Komentarz, red. K. Gil, A. Obońska, A. Wacławczyk, A. Walter, 2016, Legalis.

${ }^{43}$ Dz.Urz. UE L 21 z 28 stycznia 2015 r., s. 1.

${ }_{44}$ A. Wieśniak-Wiśniewska, M. Czerwiński, Świat podatków po projekcie BEPS, op. cit., s. $22-31$.

45 Klauzula wprowadzona została ustawą z 13 maja 2016 r. o zmianie ustawy - Ordynacja podatkowa oraz niektórych innych ustaw, Dz.U. poz. 846.

${ }^{46}$ Szerzej zob. D. Gajewski (red.), J. Glumińska-Pawlic, M. Golecki, A. Werner, Klauzula przeciwko unikaniu opodatkowania, Warszawa 2018.

${ }^{47}$ Między innymi skreślenie art. 24 ust. 3 umowy o UPO z Cyprem; brak klauzuli w art. 21 nowej umowy o UPO z Czechami; zmieniony art. 24 umowy o UPO z Indiami; 
- wprowadzenie opodatkowania dochodów dyrektorów wyłącznie w państwie ich rezydencji podatkowej ${ }^{48}$.

OECD w ramach przedstawionych działań (nr 6) zasygnalizowało konieczność wprowadzenia kilku instrumentów prawnych przeciwdziałających przyznawaniu korzyści podatkowych w niewłaściwych okolicznościach. Takim istotnym instrumentem jest tzw. klauzula głównego celu (Principle Purpose Test, PPT), która stanowi reakcję na nadużycia traktatowe (treaty abuse) ${ }^{49}$. Polska zdecydowała się formalnie na implementację klauzuli PPT na podstawie art. 7 ust. 1 Konwencji wielostronnej implementującej środki traktatowego prawa podatkowego mające na celu zapobieganie erozji podstawy opodatkowania i przenoszenia zysku ${ }^{50}$, nie wykluczając jednak wprowadzenia w drodze bilateralnych negocjacji rozszerzonych wariantów tzw. klauzuli ograniczenia korzyści LOB ${ }^{51}$.

Klauzula PPT, w odróżnieniu od ogólnych klauzul przeciwko unikaniu opodatkowania funkcjonujących w państwach OECD (w tym w Polsce), nie odwołuje się do kryterium sztuczności celem zidentyfikowania nieakceptowalnej struktury/transakcji ${ }^{52}$.

Klauzula PPT pozostawia również otwartą kwestię skutków, do których prowadzić ma jej zastosowanie. Stanowi ona expressis verbis o nieprzyzna-

zmieniony art. 24 umowy o UPO z Luksemburgiem; brak klauzuli w art. 23 nowej umowy o UPO z Malezją; skreślenie art. 23 ust. 3 w umowie o UPO z Maltą; brak klauzuli w art. 22 nowej umowy o UPO ze Słowacją; zmieniony art. 24 ust. 1 umowy o UPO ze Zjednoczonymi Emiratami Arabskimi. Zob. Ministerstwo Finansów, Wykaz umów o wymianie informacji w sprawach podatkowych, http://www.finanse.mf.gov.pl.

48 Między innymi art. 16 umowy o UPO z Cyprem; art. 19 umowy o UPO ze Zjednoczonymi Emiratami Arabskimi; art. 15 umowy o UPO z Bośnią i Hercegowiną. Zob. Ministerstwo Finansów, Wykaz umów o wymianie informacji w sprawach podatkowych, http:// www.finanse.mf.gov.pl.

${ }^{49}$ Dokonane w formie bezpośredniego nadużycia przepisów danej umowy, gdy osoba stara się obejść ograniczenia przewidziane przez taką umowę, przykładowo przez zastosowanie struktury conduit.

${ }^{50}$ Multilateral Convention to Implement Tax Treaty Related Measures to Prevent Base Erosion and Profit Shifting, podpisana w Paryżu 7 czerwca 2017 r. (zwana Konwencją MLI), http://www.oecd.org/tax/treaties/multilateral-convention-to-imlement-tax-treaty-related-measures-to-prevent-beps.htm.

51 F. Majdowski, Principle Purpose Test - nowa klauzula antyabuzywna do zwalczania nadużycia umów o unikaniu podwójnego opodatkowania. Niewygodne ( $i$ zapomniane) pytania, „Monitor Podatkowy” 2017, nr 11, s. 25-31.

52 A. Dourado, Aggressive tax planning in EU law and in the light of BEPS: The EC Recommendation on Aggressive Tax Planning and BEPS Actions 2 and 6, Intertax No. 1, 2015, s. 56; D. Weber, The reasonableness test of the Principal Purpose Test rule in OECD BEPS Action 6 (tax treaty abuse) versus the EU principle of legal certainty and the EU abuse of law case law, „Erasmus Law Review” 2017, No. 1, s. 57, https://doi.org/10.5553/elr.000081. 
niu korzyści traktatowej, nie określając wszakże, czy oznacza to, że państwo przyznające taką korzyść powinno dokonać rekonstrukcji struktury/transakcji zgodnie z jej rzeczywistym przebiegiem i w konsekwencji zastosować właściwy przepis dystrybucyjny umowy podatkowej ${ }^{53}$. Trudno więc jednoznacznie stwierdzić, czy klauzula PPT ma w tym zakresie charakter stricte penalizujący, czy też powinna być odczytywana właśnie jako norma korygująca ${ }^{54}$, która nakazuje państwu stronie umowy zastosowanie właściwego przepisu umowy podatkowej ${ }^{55}$.

Podsumowując, należy stwierdzić, że klauzula PPT może funkcjonować równolegle do innych, bardziej specyficznych klauzul antyabuzywnych, jak np. klauzula LOB czy też klauzula rzeczywistego beneficjenta bądź klauzula nieruchomościowa. Bezpośrednio potwierdza to Komentarz do PPT, który dopuszcza równoległe stosowanie klauzuli PPT oraz klauzuli $\mathrm{LOB}^{56}$.

\section{Działanie $\mathrm{nr} 7$}

Ważnym działaniem jest zapobieganie sztucznemu unikaniu statusu zakładu (Permanent Establishment) ${ }^{57}$. W szczególności istotnym problemem jest unikanie przez podatników statusu zakładu przez korzystanie z umów agencyjnych i wykorzystanie wyjątków od definicji zakładu, np. sztuczna fragmentacja działalności.

Działaniem w tym zakresie powinna być zmiana art. 5 Modelowej konwencji OECD, który pozwala w sposób zbyt szeroki wyłączyć powstanie stałego zakładu przez wykorzystanie różnych instrumentów i działań (np. wykorzystanie tzw. umów agencyjnych, zwolnień przewidzianych dla określonych rodzajów działalności pomocniczej czy też dzielenie kontraktów na wiele mniejszych). Tak więc charakter zmian powinien sprowadzać się do ich implementacji do Modelowej konwencji OECD oraz zawartych umów o $\mathrm{UPO}^{58}$.

W pierwszej kolejności należy zwrócić uwagę na kwestię dotyczącą unikania powstania stałego zakładu przez umowy agencyjne i podobne rozwiązania

53 C. Taboada, OECD Base Erosion and Profit Shifting Action 6: The General Anti-Abuse Rule, „Bulletin for International Taxation” 2015, No. 10, s. 606.

54 F. Majdowski, Principle Purpose Test, op. cit., s. 25-31.

${ }_{55}$ M. Lang, BEPS Action 6: introducing an antiabuse rule in tax treaties, „Tax Notes International" 2014, No 74, s. 661.

${ }^{56}$ Komentarz do PPT $z$ Raportu BEPS nr 6, pkt 3-4; polemicznie: A. Baez Moreno, GAARs and Treaties: from the Guiding Principle to the Principal Purpose Test. What have we gained from BEPS Action 6?, Intertax No. 6-7, 2017, s. 434, który proponuje, by klauzulę PPT stosować do przypadków rule shopping, podczas gdy klauzulę LOB do przypadków treaty shopping.

57 OECD, Preventing the Artificial Avoidance of Permanent Establishment Status. Action 7: 2015 Final Report, Paryż 2015, https://doi.org/10.1787/9789264241220-en.

${ }_{58}$ A. Wieśniak-Wiśniewska, M. Czerwiński, Świat podatków po projekcie BEPS, op. cit., s. $22-31$. 
(art. 12). Na szczególną uwagę zasługują umowy agencyjne (commissionaire arrangements) jako najczęściej stosowanej strategii służącej sztucznemu unikaniu statusu stałego zakładu, co wynika głównie z wąskiej definicji tzw. przedstawiciela zależnego zawartej w art. 5 ust. 5 Modelowej konwencji OECD ${ }^{59}$. Główną zmianą definicji przedstawiciela zależnego jest objęcie zakresem regulacji także takich stanów faktycznych, w których przedstawiciel wprawdzie nie zawiera umów w imieniu podatnika, lecz pełni wiodącą rolę w procesie ich negocjowania, nawet gdy następnie są one zawierane bezpośrednio przez tego podatnika. Ponadto, umowy nie muszą być zawarte w imieniu podatnika, wystarczy, że dotyczą one dóbr stanowiących jego własność lub usług przez tego podatnika świadczonych ${ }^{60}$.

Kolejnym istotnym obszarem w zakresie tych działań jest zmiana stosowania regulacji art. 5 ust. 4 Modelowej konwencji OECD przez między innymi zmianę katalogu wyłączeń zawartych w tym przepisie, szczególnie w zakresie pkt a-d ${ }^{61}$. Wynika to z przekonania, że jedynie działalność nieodgrywająca istotnej roli $\mathrm{w}$ funkcjonowaniu danego przedsiębiorstwa ( $\mathrm{w}$ ramach określonego modelu biznesowego) powinna być kwalifikowana jako tzw. czynności o charakterze przygotowawczym albo pomocniczym. W innym wypadku, nawet gdy dana placówka służy jedynie wydawaniu towarów nabywcom, jeżeli jej charakter w kontekście funkcjonowania całego przedsiębiorstwa jest istotny, nie powinna korzystać $\mathrm{z}$ wylączenia przewidzianego przez art. 5 ust. 4 Modelowej konwencji OECD. Podobnie wyłączenie z art. 5 ust. 4 Modelowej konwencji OECD nie powinno mieć zastosowania do sytuacji, kiedy podatnik (lub podmiot blisko z nim powiązany ${ }^{62}$ ) posiada kilka placówek, których działalność rozpatrywana łącznie nie mogłaby być uznana za pomocniczą lub przygotowawczą. Zmiana ta ma znaczenie zasadnicze, gdyż wyłącza możliwość dzielenia działalności prowadzonych przez stałe placówki w danym państwie nie tylko przez jednego podatnika, ale także w grupie podmiotów ze sobą powiązanych ${ }^{63}$.

59 Zob. zalecenie Komisji (UE) 2016/136 z 28 stycznia 2016 r. w sprawie wdrażania środków przeciwdziałających nadużyciom postanowień konwencji podatkowych, Dz.Urz. UE L z 2 lutego $2016 \mathrm{r}$.

${ }^{60}$ M. Leconte, M. Raińczuk, Konwencja Wielostronna (BEPS działanie nr 15), op. cit., s. $19-20$.

${ }^{61}$ Punkty te dotyczą w szczególności placówek służących składowaniu, dostarczaniu lub zakupowi dóbr, przetwarzaniu ich przez inne przedsiębiorstwo oraz zbieraniu informacji dla przedsiębiorstwa.

${ }_{62}$ Podmiot blisko powiązany został zdefiniowany w art. 15 Konwencji wielostronnej. Definicja ta ma zastosowanie do instytucji pojawiających się w art. 12, 13 i 14 Konwencji. Zasadniczo powiązanie w rozumieniu art. 15 zachodzić będzie, gdy dany podmiot posiada (pośrednio lub bezpośrednio) co najmniej 50\% głosów/wartości udziałów w drugim podmiocie lub podmiot trzeci posiada taki udział w obu podmiotach.

${ }_{63}$ M. Leconte, M. Raińczuk, Konwencja Wielostronna (BEPS działanie nr 15), op. cit., s. $19-20$. 
Kolejnym istotnym działaniem jest dzielenie kontraktów na kontrakty mniejsze (w zakresie czasu ich realizacji), co zostało uznane za metodę unikania powstania zakładu w formie tzw. placu budowy. Art. 5 ust. 3 Modelowej konwencji OECD wprowadza bowiem okres 12 miesięcy, którego przekroczenie jest niezbędne do uznania, że stała placówka w postaci placu budowy stanowi dla podatnika zakład. Modelowa konwencja wprowadza modyfikację, zgodnie z którą czas trwania czynności wykonywanych na jednej budowie przez podatnika lub też podmioty blisko powiązane podlega sumowaniu ${ }^{64}$.

Rozwiązania zawarte w części dotyczącej sztucznego unikania statusu stałego zakładu nie zostały uznane za konieczne dla osiągnięcia minimalnego standardu, dlatego państwa strony mają możliwość rezygnacji z ich wprowadzania.

\section{Działanie nr 8}

Istotnym działaniem jest zapewnienie, by ceny transferowe odpowiadały wartości aktywów niematerialnych ${ }^{65}$. Jest to ważne ze względu na fakt, że wykorzystywane są ceny transferowe dla transakcji dotyczących wartości niematerialnych do niewłaściwej alokacji zysków generowanych przez cenne wartości niematerialne w celu unikania opodatkowania.

Za kluczowe należy uznać zmiany w rozporządzeniu Ministra Finansów w sprawie sposobu i trybu określania dochodów osób prawnych w drodze oszacowania oraz sposobu i trybu eliminowania podwójnego opodatkowania osób prawnych w przypadku korekty zysków podmiotów powiązanych (t.j. Dz.U. 2014, poz. 1186), tak by brały pod uwagę wytyczne OECD. Dlatego stała się konieczna pełna modyfikacja tego rozporządzenia w zakresie transakcji angażujących dobra niematerialne odnośnie do alokacji zysków z wartości niematerialnej ${ }^{66}$.

\section{Działanie $\mathrm{nr} 9$}

Dziewiąte działanie ma na celu zapewnienia zgodności cen transferowych z kreowaniem wartości ryzyka kapitału ${ }^{67}$. Ma to przeciwdziałać wykorzystywaniu cen transferowych przy umownej alokacji ryzyk i zysków niezgodnej z działalnością faktycznie wykonywaną.

Należy pamiętać, że modyfikacja rozporządzenia konieczna będzie co do umownej alokacji ryzyk. Dotyczy to również zysków wynikających z tych ryzyk, które powinny korespondować z działalnością rzeczywiście prowadzoną,

${ }^{64}$ Ibidem.

65 OECD, Aligning Transfer Pricing Outcomes with Value Creation. Action 8-10: 2015 Final Report, Paryż 2015, https://doi.org/10.1787/9789264241244-en.

${ }^{66}$ A. Wieśniak-Wiśniewska, M. Czerwiński, Świat podatków po projekcie BEPS, op. cit., s. 22-31.

${ }^{67}$ OECD, Aligning Transfer Pricing Outcomes with Value Creation. Action 8-10: 2015 Final Report, op. cit. 
a poziom zwrotu $\mathrm{z}$ kapitału zaangażowanego przez członka grupy powinien korespondować z poziomem aktywności podjętej przez spółkę angażującą kapitał.

\section{Działanie nr 10-11}

Dziesiąte działanie to zapewnienie zgodności cen transferowych $\mathrm{z}$ kreowaniem wartości innych transakcji obarczonych wysokim ryzykiem ${ }^{68}$. Ma to przeciwdziałać wykorzystywaniu cen transferowych jako możliwości przenoszenia na podmioty powiązane kosztów transakcji, które - z punktu widzenia podmiotów niepowiązanych - nie są racjonalne biznesowo (np. obciążenie $\mathrm{z}$ tytułu tzw. managament fees czy tzw. head office expenses).

Jedenaste działanie dotyczy ustanowienia metodologii zbierania oraz analizowania danych dotyczących zjawiska zmniejszania podstawy opodatkowania i transferu zysków ${ }^{69}$. Ma na celu zapobiegać brakom w zakresie techniki/mechanizmów pozwalających na zidentyfikowanie/powiązanie alokacji zysków między poszczególnymi jurysdykcjami a faktycznymi działaniami powodującymi powstanie wartości dodanej podlegającej opodatkowaniu ${ }^{70}$.

Działania te mają sprzyjać stworzeniu przepisów wewnątrzkrajowych w zakresie nałożenia obowiązku ujawniania agresywnych strategii planowania podatkowego przez podatników.

$\mathrm{W}$ działania dotyczące zbierania i wymiany danych ${ }^{71}$ wpisuje się również wprowadzanie do nowo zawieranych i modyfikowanych umów o UPO pełnej klauzuli wymiany informacji, $w$ tym informacji bankowej ${ }^{72}$, poszerzania zakresu terytorialnego Konwencji o wzajemnej pomocy administracyjnej w sprawach podatkowych z 25 stycznia 1988 r. wraz z Protokołem zmieniającym Konwencję o wzajemnej pomocy administracyjnej w sprawach podatkowych z 27 maja 2010 r. ${ }^{73}$, implementacja dyrektywy Rady 2011/16/UE z 15 lutego 2011 r. w sprawie współpracy administracyjnej w dziedzinie opodatkowania i uchylającej dyrektywę 77/799/EWG ${ }^{74}$, prowadzenie prac nad implementacją dyrekty-

68 Ibidem.

${ }^{69}$ OECD, Measuring and Monitoring BEPS. Action 11: 2015 Final Report, Paryż 2015, https://doi.org/10.1787/9789264241343-en.

70 A. Wieśniak-Wiśniewska, M. Czerwiński, Świat podatków po projekcie BEPS, op. cit., s. $22-31$.

${ }^{71}$ F. Majdowski, R. Wielgórski, Nowy ład światowy w zakresie wymiany informacji podatkowych?, „Przegląd Podatkowy” 2014, nr 8, s. 32-39.

${ }_{72}$ Między innymi art. 26 umowy o UPO z Maltą; art. 24 umowy o UPO z Czechami; art. 26 umowy o UPO z Islandią; art. 27 umowy o UPO z Luksemburgiem; art. 27 umowy o UPO z Cyprem; art. 26 umowy o UPO z Malezją; art. 27 umowy o UPO ze Słowacją; art. 27 umowy o UPO z Indiami. Zob. Ministerstwo Finansów, Wykaz umów o wymianie informacji $w$ sprawach podatkowych, http://www.finanse.mf.gov.pl.

${ }_{73}$ Dz.U. 1998, nr 141, poz. 913, ze zm.

${ }^{74}$ Dz.Urz. UE L 64 z 11 marca 2011 r., s. 1, ze zm. 
wy Rady 2014/107/UE z 9 grudnia 2014 r. zmieniającej dyrektywę 2011/16/UE w zakresie obowiązkowej automatycznej wymiany informacji w dziedzinie opodatkowania ${ }^{75}$ i dyrektywy Rady (UE) 2015/2376 z 8 grudnia 2015 r. zmieniającej dyrektywę 2011/16/UE w zakresie obowiązkowej automatycznej wymiany informacji w dziedzinie opodatkowania ${ }^{76}$, wdrażanie ustawodawstwa FATCA ${ }^{77}$, wprowadzenie procedury Common Reporting Standard (CRS ${ }^{78}$.

\section{Działanie $\mathrm{nr}$ 12-13}

Kolejne działanie ma na celu wprowadzenie wymogu ujawniania przez podatników stosowanych agresywnych strategii podatkowych ${ }^{79}$. Problemem są braki uregulowań krajowych obligujących podatników do ujawniania stosowanych przez nich (agresywnych) strategii podatkowych. W konsekwencji, niemożność zidentyfikowania przez władze podatkowe sytuacji, które potencjalnie mogą mieć związek z przenoszeniem zysków między jurysdykcjami różnych państw.

Mając te kwestie na uwadze, rekomendowane jest stworzenie przepisów krajowych w zakresie nałożenia obowiązku ujawniania agresywnych strategii planowania podatkowego przez podatników. Polska nie zdecydowała się dotąd na wprowadzenie mechanizmu obowiązkowego ujawniania przez podatników strategii podatkowych. Jednak należy zauważyć, że w tę tendencję wpisują się komunikaty publikowane przez Ministerstwo Finansów zachęcające podmioty powiązane, stosujące optymalizację podatkową, do dobrowolnej korekty deklaracji podatkowej za lata ubiegłe w trybie art. 81 Ordynacji podatkowej w zamian za zmniejszenie odsetek i zapowiadające skoncentrowanie kontroli na takich podmiotach w latach $2016-2017^{80}$.

75 Dz.Urz. UE L 359 z 16 grudnia 2014 r., s. 1.

76 Dz.Urz. UE L 332 z 18 grudnia 2015 r., s. 1.

77 Ustawa z 9 października 2015 r. o wykonywaniu umowy między Rządem Rzeczypospolitej Polskiej a Rządem Stanów Zjednoczonych Ameryki w sprawie poprawy wypełniania międzynarodowych obowiązków podatkowych oraz wdrożenia ustawodawstwa FATCA, Dz.U. poz. 1712.

${ }^{78}$ Polska zobowiązała się do tego w deklaracji podpisanej 29 października $2014 \mathrm{r}$. w Berlinie. Zob. Multilateral Competent Authority Agreement on Automatic Exchange of Financial Account Information, http://www.oecd.org/tax/transparency/technical-assistance/ aeoi/whatisthemultilateralcompetentauthorityagreement.htm. A. Wieśniak-Wiśniewska, M. Czerwiński, Świat podatków po projekcie BEPS, op. cit., s. 22-31.

79 OECD, Mandatory Disclosure Rules. Action 12: 2015 Final Report, Paryż 2015, https:// doi.org/10.1787/9789264241442-en.

${ }^{80}$ Zob. np. komunikat z 21 października 2015 r., Ceny transferowe - zamierzenia Ministerstwa Finansów na rok 2016 oraz komunikat z 5 lutego 2016 r., Ceny transferowe - dotychczasowe działania i zamiary MF, http://www.mf.gov.pl/ministerstwo-finansow/wiadomosci/komunikaty. A. Wieśniak-Wiśniewska, M. Czerwiński, Świat podatków po projekcie BEPS, op. cit., s. 22-31. 
Trzynaste działanie ma na celu powtórne zdefiniowanie dokumentacji cen transferowych ${ }^{81}$. Informacje, jakie można uzyskać z przeanalizowania dokumentacji cen transferowych, nie są wystarczające w obszarach związanych z uzyskaniem pełnego obrazu funkcjonowania grupy podmiotów powiązanych, w tym miejsc prowadzenia działalności, rodzaju realizowanych transakcji, jak również miejsc faktycznie wykazywanego dochodu do opodatkowania.

Istotnymi zmianami w tym zakresie będzie zasada trójstopniowego podejścia do dokumentacji obejmującej przygotowanie tzw. local file, master file oraz Coutry-by-Coutry Reporting (CbCR) ${ }^{82}$.

Z dniem 1 stycznia 2015 r. ustawą nowelizującą z 29 sierpnia 2014 r. zmieniono przepisy dotyczące dokumentacji podatkowej i szacowania dochodów w zakresie rozliczeń wynikających z zawarcia spółki osobowej albo zawarcia umowy (handlowej, gospodarczej) przez wspólnika spółki osobowej ze spółką osobową, przesądzając obowiązek w tym zakresie ${ }^{83}$.

Ponadto od 1 stycznia 2017 r. weszły w życie regulacje ${ }^{84}$ dotyczące obowiązku przygotowywania trójstopniowej dokumentacji podatkowej w zakresie transakcji z podmiotami powiązanymi. Pierwszym elementem dokumentacji jest dokument lokalny (local file), zawierający informacje dotyczące transakcji z podmiotami powiązanymi i uzasadniający rynkowość przyjętych warunków (art. 9a ust. 2b pkt. 1 i pkt 3-5 u.p.d.p.). Drugi element to dokument grupowy (master file) przygotowywany na poziomie całej grupy kapitałowej (art. 9a ust. 2 d u.p.d.p. ${ }^{85}$. Trzecią część stanowi obowiązek raportowania określonych informacji (CbCR) dla największych grup/podatników (art. 27 ust. 6 u.p.d.p.). Ponadto podatnicy zobowiązani są do składania urzędom skarbowym oświadczenia o sporządzeniu kompletnej dokumentacji cen transferowych do dnia upływu terminu złożenia zeznania podatkowego za dany rok (art. 9a ust. 7 u.p.d.p.). Na uwagę zasługuje również fakt, że w zakresie cen transferowych doszło do podwyższenia progu powiązań kapitałowych (z 5\% do 25\%), (art. 11 ust. 5a u.p.d.p.).

Należy zwrócić uwagę, że 27 stycznia 2016 r. Polska i 30 innych państw podpisały wielostronne porozumienie w sprawie automatycznej wymiany in-

${ }^{81}$ OECD, Transfer Pricing Documentation and Country-by-Country Reporting. Action 13: 2015 Final Report, Paryż 2015, https://doi.org/10.1787/9789264241480-en.

82 A. Wieśniak-Wiśniewska, M. Czerwiński, Świat podatków po projekcie BEPS, op. cit., s. $22-31$.

83 J. Sekita, Spółki osobowe a przepisy o cenach transferowych. Stan prawny przed $i$ po 1 stycznia 2015 r., „Przegląd Podatkowy” 2015, nr 2, s. 27-32.

${ }^{84}$ Ustawa z 9 października 2015 r. o zmianie ustawy o podatku dochodowym od osób fizycznych, ustawy o podatku dochodowym od osób prawnych oraz niektórych innych ustaw, Dz.U. poz. 1932.

${ }_{85}$ A. Wieśniak-Wiśniewska, M. Czerwiński, Świat podatków po projekcie BEPS, op. cit., s. $22-31$. 
formacji na temat wielonarodowych grup kapitałowych zawartych $\mathrm{w}$ formularzach dotyczących raportowania według państw $(\mathrm{CbCR})^{86}$, zatem polskie organy podatkowe uzyskały dostęp do wrażliwych informacji na temat grup kapitałowych składających formularz w którymkolwiek z państw sygnatariu$\mathrm{szy}^{87}$.

\section{Działanie $\mathrm{nr}$ 14-15}

Czternastym działaniem jest usprawnienie mechanizmów rozwiązywania sporów międzynarodowych ${ }^{88}$. Problemem są istniejące braki w zakresie rozwiązań/uregulowań usuwających przeszkody, które utrudniają państwom rozwiązywanie sporów $\mathrm{w}$ ramach procedury wzajemnego porozumiewania się (Mutual Agreement Procedure, MAP), włączając przypadki braku przepisów arbitrażowych w wielu umowach o UPO bądź też sytuacje, gdy dostęp do MAP i arbitrażu może być poważnie ograniczony ${ }^{89}$.

Działania te są wdrażane przez Konwencję wielostronną, która odnosi się wprost do procedur rozwiązywania sporów powstałych w ramach stosowania umów o UPO. Artykuły 16 i 17 Konwencji wielostronnej mają na celu wprowadzenie do obowiązujących umów odpowiednio art. 25 i 9 ust. 2 Modelowej konwencji OECD, a zatem procedury wzajemnego porozumiewania się oraz korekty zysków przedsiębiorstwa powiązanego (corresponding adjustment) ${ }^{90}$, w przypadku gdy zawarta umowa postanowień tych nie przewiduje.

Jeżeli chodzi o art. 18-26 Konwencji wielostronnej, to wprowadzają one nową instytucję arbitrażu, przy czym konstrukcja ta będzie miała zastosowanie jedynie do państw, które je wybiorą i dokonają notyfikacji. Według tych regulacji podatnik będzie uprawniony do żądania rozstrzygnięcia swojej sprawy wynikającej ze stosowania umowy o unikaniu podwójnego opodatkowania przez dwa państwa przez wybranych arbitrów, pod warunkiem że procedura wzajemnego porozumiewania się nie pozwoliła na rozstrzygnięcie sprawy w ciągu 2 lat ${ }^{91}$.

${ }^{86}$ Multilateral Competent Authority Agreement on the Exchange of Country-by-Country Reports, http://www.oecd.org/tax/exchange-of-tax-information/cbc-mcaa.pdf.

87 A. Wieśniak-Wiśniewska, M. Czerwiński, Świat podatków po projekcie BEPS, op. cit., s. $22-31$.

${ }^{88}$ OECD, Making Dispute Resolution Mechanisms More Effective. Action 14: 2015 Final Report, Paryż 2015, https://doi.org/10.1787/9789264241633-en.

89 A. Wieśniak-Wiśniewska, M. Czerwiński, Świat podatków po projekcie BEPS, op. cit., s. $22-31$.

90 M. Zasiewska, A. Oktawiec, J. Chorązka, Umowy o unikaniu podwójnego opodatkowania. Komentarz, Warszawa 2011, s. 182.

${ }_{91}$ M. Leconte, M. Raińczuk, Konwencja Wielostronna (BEPS działanie $n r$ 15), op. cit., s. 19-20; A. Wieśniak-Wiśniewska, M. Czerwiński, Świat podatków po projekcie BEPS, op. cit., s. 22-31. 
Piętnaste działanie rekomenduje stworzenie wielostronnej umowy umożliwiającej wprowadzenie Planu działań BEPS oraz modyfikacji istniejących umów o UPO ${ }^{92}$. Zmiany wprowadzone w efekcie Planu działań BEPS wymagają - dla zapewnienia skuteczności oraz ograniczenia BEPS - sprawnej implementacji za pośrednictwem wielostronnego instrumentu (wielostronnej umowy).

\section{Podsumowanie}

Analizując zaprezentowane przez OECD działania BEPS, należy stwierdzić, że mają one istotny wpływ na zmianę regulacji podatkowych, zarówno w wymiarze międzynarodowym, jak i wewnątrzkrajowym.

Niewątpliwie należy uznać, iż Konwencja wielostronna jest ważnym aktem prawnym, który może przynieść wiele pozytywnych skutków dla państw OECD i G-20 przy rozwiązywaniu kwestii podniesionych w poszczególnych raportach BEPS. Konkludując, należy stwierdzić, że przy tak dużej liczbie umów o unikaniu podwójnego opodatkowania, które w znacznej mierze kształtują strukturę opodatkowania dochodów uzyskiwanych przez podmioty działające transgranicznie, wielostronna umowa międzynarodowa jest optymalnym rozwiązaniem, które pozwala na dokonanie koniecznych zmian. Postulowanie zmian wyrażonych w opracowywanych przez OECD raportach nie będzie skutkowało realnymi zmianami, które w konsekwencji prowadziłyby do zmniejszenia zjawiska unikania opodatkowania.

Wydaje się, że istotnym zagrożeniem dla Konwencji może być jej ratyfikacja przez poszczególne państwa. Może bowiem okazać się, iż Konwencja nie osiągnie przewidywanego skutku. Wynikać to może zarówno z rezygnacji przez wiele państw z rozwiązań, które nie zostały przewidziane jako standard minimalny (między innymi te, które dotyczą unikania powstania stałego zakładu), jak i wyboru różnych (odmiennych) sposobów przez poszczególne państwa strony, co utrudni możliwość ich implementowania do już zawartych umów o unikaniu podwójnego opodatkowania.

Na uznanie zasługuje determinacja państw OECD, która przejawia się w pracach nad BEPS, zmierzających do zmian międzynarodowego prawa podatkowego. Tendencje te można również dostrzec w przyjętej dyrektywie Rady $(\mathrm{UE})^{93}$ ustanawiającej przepisy mające na celu przeciwdziałanie praktykom unikania opodatkowania, które mają bezpośredni wpływ na funkcjonowanie rynku wewnętrznego.

Niewątpliwie kluczową konstrukcją dla międzynarodowego opodatkowania dochodów i zysków osiąganych przez przedsiębiorstwa międzynarodowe

92 OECD, Developing a Multilateral Instrument to Modify Bilateral Tax Treaties. Action 15: 2015 Final Report, Paryż 2015, https://doi.org/10.1787/9789264241688-en.

${ }^{93}$ Dyrektywa Rady (UE) 2016/1164 z 12 lipca 2016 r. 
jest wprowadzona do umów podatkowych klauzula PPT. Jednak istotną słabością klauzuli PPT mogą okazać się zarzuty jej niezgodności z prawem unijnym. Wydaje się, że rozwiązaniem tej kwestii byłoby usankcjonowanie takiej klauzuli w formie wtórnego aktu prawnego (dyrektywy), co nastąpiło w przypadku innych prac OECD w ramach projektu BEPS poprzez przyjęcie dyrektywy przeciwko unikaniu opodatkowania.

W innym wypadku państwa członkowskie, działając bez „kontrolowanej koordynacji”, wprowadzając klauzulę PPT w wersji niezmodyfikowanej, będą narażone na ryzyko przegrania ewentualnego sporu przed Trybunałem Sprawiedliwości UE. Należy bowiem zauważyć, że linia orzecznicza TSUE nie jest w pełni ukształtowana, co powoduje, że nie można z całkowitą pewnością wykluczyć nawet sytuacji, gdy w przyszłości TSUE zaakceptuje nowe nadrzędne uzasadnienie interesu publicznego (overriding reason in the public interest) $\mathrm{w}$ formie narzędzi antyabuzywnych, wypracowanych i uzgodnionych na arenie międzynarodowej współpracy, jakim jest projekt OECD BEPS.

Ponadto, analizując wdrożenie wszystkich działań BEPS, należy skonstatować, że będzie to zasadnicza zmiana międzynarodowego prawa podatkowego polaryzującego na poszczególne ustawodawstwa wewnątrzkrajowe państw członkowskich. Oczywiście proces wdrażania będzie niewątpliwie trwał, a intensywność jego wdrażania w poszczególnych państwach członkowskich będzie zróżnicowana. Jednak już na tym etapie można stwierdzić, że dokonywane zmiany w państwach OECD (w tym Polsce) w istotny sposób będą się przyczyniały do przeciwdziałania międzynarodowemu unikaniu opodatkowania.

\section{Bibliografia}

Baez Moreno A., GAARs and Treaties: from the Guiding Principle to the Principal Purpose Test. What have we gained from BEPS Action 6?, „Intertax” 2017, No. 6-7.

Dourado A., Aggressive tax planning in EU law and in the light of BEPS: The EC Recommendation on Aggressive Tax Planning and BEPS Actions 2 and 6, „Intertax” 2015, No. 1.

Dudzic M., Przegląd prac OECD związanych z BEPS w kontekście suwerenności państwa, „Kwartalnik Prawa Podatkowego” 2014, nr 3.

Eberhartinger E., Petutschnig M., Practicing Experts' Views on BEPS: A Critical Analysis, WU International Taxation Research Paper Series, 2015, No. 27.

Engelem F., Some Observations on the Legal Status of the Commentaries on the OECD Model, „Bulletin for International Taxation” 2006, No 3.

Glumińska-Pawlic J., Golecki M., Werner A., Klauzula przeciwko unikaniu opodatkowania, Warszawa 2018.

Gil K., Komentarz do art. 22c [w:] Podatek dochodowy od osób prawnych. Komentarz, red. K. Gil, A. Obońska, A. Wacławczyk, A. Walter, 2016, Legalis. 
Krempa S., Woźniakiewicz P., Niedostateczna kapitalizacja - zasady odliczania odsetek do kosztów uzyskania przychodów od 2015 r. Metoda podstawowa (1), „Przegląd Podatkowy" 2014, nr 12.

Krempa S., Woźniakiewicz P., Niedostateczna kapitalizacja - zasady odliczania odsetek do kosztów uzyskania przychodów od 2015 r. Metoda alternatywna oraz przepisy międzyczasowe (2), „Przegląd Podatkowy” 2015, nr 1.

Kukulski Z., Konwencja Modelowa OECD i Konwencja Modelowa ONZ w polskiej praktyce traktatowej, Warszawa 2015.

Kuźniacki B., Polskie CFC rules $w$ świetle międzynarodowego prawa podatkowego. Wybrane aspekty wystapienia ryzyka niezgodności CFC rules $z$ umowami o unikaniu podwójnego opodatkowania (1), „Przegląd Podatkowy” 2015, nr 1.

Kuźniacki B., Polskie CFC rules w świetle międzynarodowego prawa podatkowego. Zagraniczna $i$ polska praktyka legislacyjna $w$ zakresie relacji pomiędzy CFC rules a umowami UPO, „Przegląd Podatkowy” 2015, nr 3.

Lang M., BEPS Action 6: introducing an antiabuse rule in tax treaties, Tax Notes International, 2014, No 74, doi.org/10.2139/ssrn.2500827.

Leconte M., Raińczuk M., Konwencja Wielostronna (BEPS działanie nr 15) - omówienie najistotniejszych zagadnień, „Monitor Podatkowy” 2017, nr 5.

Majdowski F., Implementacja klauzuli antyhybrydowej oraz tzw. małej klauzuli antyabuzywnej do ustawy o podatku dochodowym od osób prawnych na skutek „uszczelnienia” dyrektywy o spółkach matkach i spółkach córkach, „Przegląd Podatkowy” 2016, nr 2 .

Majdowski F., Principle Purpose Test - nowa klauzula antyabuzywna do zwalczania nadużycia umów o unikaniu podwójnego opodatkowania. Niewygodne (i zapomniane) pytania, „Monitor Podatkowy” 2017, nr 11.

Majdowski F., Wielgórski R., Nowy ład światowy w zakresie wymiany informacji podatkowych?, „Przegląd Podatkowy” 2014, nr 8, 2014.

Malicka M., Zalasiński A., Rola oficjalnego komentarza do Modelu Konwencji OECD w interpretacji umów dotyczących unikania podwójnego opodatkowania opartych na tym Modelu, „Kwartalnik Prawa Podatkowego” 2005, nr 1.

Mączyński D., Międzynarodowe prawo podatkowe, Warszawa 2015.

Missala W., Opodatkowanie zagranicznych spótek kontrolowanych (CFC) - co czeka polskich przedsiębiorców?, „Przegląd Podatkowy” 2014, nr 11.

OECD, About Base Erosion and Profit Shifting (BEPS), http://www.oecd.org/ctp/beps-about.htm.

OECD, Addessing the Tax Challenges of the Digital Economy. Action 1: 2015 Final Report, Paryż 2015, https://doi.org/10.1787/9789264241046-en.

OECD, Aligning Transfer Pricing Outcomes with Value Creation. Action 8-10: 2015 Final Report, Paryż 2015, https://doi.org/10.1787/9789264241244-en.

OECD, Countering Harmful Tax Practices More Effectively, Taking into Account Transparency and Substance. Action 5: 2015 Final Report, Paryż 2015, https://doi. org/10.1787/9789264241190-en. 
OECD, Designing Effective Controlled Foreign Company Rules. Action 3: 2015 Final Report, Paryż 2015, https://doi.org/10.1787/9789264241152-en.

OECD, Developing a Multilateral Instrument to Modify Bilateral Tax Treaties. Action 15: 2015 Final Report, Paryż 2015, https://doi.org/10.1787/9789264241688-en.

OECD, Limiting Base Erosion Involving Interest Deductions and Other Financial Payments. Action 4: 2015 Final Report, Paryż 2015, https://doi.org/10.1787/9789264241 176-en.

OECD, Making Dispute Resolution Mechanisms More Effective. Action 14: 2015 Final Report, Paryż 2015, https://doi.org/10.1787/9789264241633-en.

OECD, Mandatory Disclosure Rules. Action 12: 2015 Final Report, Paryż 2015, https:// doi.org/10.1787/9789264241442-en.

OECD, Measuring and Monitoring BEPS. Action 11: 2015 Final Report, Paryż 2015. https://doi.org/10.1787/9789264241343-en.

OECD, Neutralising the Effects of Hybrid Mismatch Arrangements. Action 2: 2015 Final Report, Paryż 2015, https://doi.org/10.1787/9789264241138-en.

OECD, Preventing the Artificial Avoidance of Permanent Establishment Status. Action 7: 2015 Final Report, Paryż 2015, https://doi.org/10.1787/9789264241220-en.

OECD, Preventing the Granting of Treaty Benefits in Inappropriate Circumstances. Action 6: 2015 Final Report, Paryż 2015, https://doi.org/10.1787/9789264241695-en.

OECD, Transfer Pricing Documentation and Country-by-Country Reporting. Action 13: 2015 Final Report, Paryż 2015, https://doi.org/10.1787/9789264241480-en.

Olesińska A., Klauzula ogólna zapobiegająca unikaniu opodatkowania, Toruń 2016.

Sekita J., Spótki osobowe a przepisy o cenach transferowych. Stan prawny przed i po 1 stycznia 2015 r., „Przegląd Podatkowy” 2015, nr 2.

Taboada C., OECD Base Erosion and Profit Shifting Action 6: The General Anti-Abuse Rule, „Bulletin for International Taxation” 2015, No. 1.

Uss M., Cele umów o unikaniu podwójnego opodatkowania, „Kwartalnik Prawa Podatkowego" 2008, nr 3-4.

The Interpretation of Income Tax Treaties with Particular Reference to the Commentaries on the OECD Model, red. D.A. Ward, BFD 2005.

Weber D., The reasonableness test of the Principal Purpose Test rule in OECD BEPS Action 6 (tax treaty abuse) versus the EU principle of legal certainty and the EU abuse of law case law, „Erasmus Law Review” 2017, No. 1, https://doi.org/10.5553/elr.000081.

Wieśniak-Wiśniewska A., Czerwiński M., Świat podatków po projekcie BEPS i jego wpływ na polskich podatników, „Przegląd Podatkowy” 2016, nr 6.

Wilk M., Klauzula rzeczywistego beneficjenta (beneficial ownership) po zmianach w Komentarzu do Konwencji Modelowej OECD w sprawie podatku od dochodu i majątku $z 2014$ r., „Przegląd Podatkowy” 2015, nr 9.

Vogel K., The Influence of the OECD Commentaries on Treaty Intepretation, „Bulletin for International Taxation" 2000, No. 12.

Zasiewska M., Oktawiec A., Chorązka J., Umowy o unikaniu podwójnego opodatkowania. Komentarz, Warszawa 2011. 


\section{Akty prawne}

Ustawa z 15 lutego 1992 r. o podatku dochodowym od osób prawnych, Dz.U. nr 21, poz. 86 , ze zm.

Ustawa z 29 sierpnia 1997 r. ustawa - Ordynacja podatkowa, t.j. Dz.U. 2015, poz. 613, ze zm.

Ustawa z 25 lipca 2014 r. o zmianie ustawy o podatku od towarów i usług oraz ustawy Ordynacja podatkowa, Dz.U. poz. 1171.

Ustawa z 29 sierpnia 2014 r. o zmianie ustawy o podatku dochodowym od osób prawnych, ustawy o podatku dochodowym od osób fizycznych oraz niektórych innych ustaw, Dz.U. poz. 1328, ze zm.

Ustawa z 9 października 2015 r. o wykonywaniu umowy między Rządem Rzeczypospolitej Polskiej a Rządem Stanów Zjednoczonych Ameryki w sprawie poprawy wypełniania międzynarodowych obowiązków podatkowych oraz wdrożenia ustawodawstwa FATCA, Dz.U. poz. 1712.

Ustawa z 9 października 2015 r. o zmianie ustawy o podatku dochodowym od osób fizycznych, ustawy o podatku dochodowym odo osób prawnych oraz niektórych innych ustaw, Dz.U. poz. 1932.

Rozporządzenie Ministra Finansów z 23 kwietnia 2015 r. w sprawie określenia krajów i terytoriów stosujących szkodliwą konkurencję podatkową w zakresie podatku dochodowego od osób prawnych, Dz.U. poz. 600. 